\title{
ABB-ABC-ABE-ABM Approach for Implementation in the Economic Entities from Energy Industry
}

\author{
Dan Ioan Topor \\ Dept. of Finance and Accounting, 1 Decembrie 1918 University, Alba-Iulia, Romania \\ E-mail: dan.topor@yahoo.com \\ Sorinel Capusneanu \\ Dept. of Finance, Banking and Accountancy, Dimitrie Cantemir Christian University, \\ Bucharest, Romania \\ E-mail: sorinelcapusneanu@gmail.com
}

Dana Maria Constantin (Oprea)

Dept. of Meteorology and Hydrology, Bucharest University, Romania

E-mail: oprea.constantin@geo.unibuc.ro

\begin{abstract}
Cristian Marian Barbu
Dept. of Management-Marketing, Artifex University, Bucharest, Romania

E-mail: doctrine.economice@gmail.com
\end{abstract}

Ileana Sorina Rakos (Boca)

Dept. of Economic Sciences, Petrosani University, Romania

E-mail: nihilsinedeo_68@yahoo.com

Received: Nov. 7, 2017 Accepted: Nov. 15, 2017 Published: Nov. 20, 2017

doi:10.5296/bmh.v5i2.12169 URL: http://dx.doi.org/10.5296/bmh.v5i2.12169 


\section{Abstract}

The purpose of this article lies in demonstrating the effectiveness of four connection methods ABB-ABC-ABE-ABM conducive to successful implementation and improving the performance of an economic entity. The objectives of this study are focused on: (1) the application of $\mathrm{ABB}-\mathrm{ABC}-\mathrm{ABE}-\mathrm{ABM}$ within an economic entity within the energetic industry and (2) highlighting performances, including environmental performance. In the framework of this article the contributions are brought by the mix of methods on the national and international level, namely the modalities and stages of their specific within an economic entity. Environmental components are addressed within the mix of economic entity methods used, their benefits and limitations. Based on case study prepared by the authors, the results of applied methods mix to improve environmental performance within the surveyed entity are presented. The article ends with the conclusions of the authors related to the efficiency of the use of the ABB-ABM-ABC-ABE for improving performance, including environmental performance within the surveyed entity.

Keywords: ABC, ABB, ABM, ABE, Emissions, Performance 


\section{Introduction}

Technological innovation and changes in the business environment triggered by global competition have led to innovations in the use of financial information and the non-financial entities. Environmental component is becoming more and more present in these financial and non-financial statements, offering data on costs and performance in terms of processes, activities, services and customers. To obtain on-time reliable information on costs, managers have turned to reshape some devoted managerial accounting systems to benefit from additional sources of information related to the environment. Remodeling cost calculation systems has brought some significant contributions of information not only for managers or decision makers, but also organizational culture. Relying on multiple integration tools for measuring and monitoring the performance of economic entities, the contemporary costs calculation methods have adopted many of these and thus contribute to the production of complex information and reliable required decisions of managers or decision-makers.

The increasingly application of more mix cost calculation methods led us in studying certain aspects of environmental integration regarding the $\mathrm{ABE}$ method under the triptych $\mathrm{ABB}-\mathrm{ABC}-\mathrm{ABM}$ in the case of economic entities in energy industry based on fossil fuel (coal) from Romania. The central goals of this article focus around two issues: (1) the application of ABB-ABC-ABE-ABM system within an economic entity within the energy industry and (2) highlighting performances, including environmental performance thereof.

\section{Literature Review}

ABC method is one of the most controversial methods of cost calculation in terms of the advantages and disadvantages offered by implementing in various activity sectors or branches of the savings on the different continents. Starting from the limitations offered by traditional methods of cost calculation, the experts have been trying to find solution for the identification of real costs of products, services or executed works, and one of these was the Activity-Based Costing $(A B C)$ method. From its appearance, ABC has seen several variants more or less extensive in respect of cost management or calculation, be simple, or in combination with other methods.

In the past 20 years the experts have also begun to consider environmental costs relating to the emissions in the environment, both in the financial accounting and managerial accounting plan. We can rely on the research undertaken by specialists on various components of the environment: emissions into the atmosphere (Depoeres, 2000; Hughes et al., 2001; Deegan, 2002; Chavent et al., 2010); worldwide environmental reporting (Holland \& Foo, 2003; Nyquist, 2003; Jorgensen \& Sodorstrom, 2007; Yusoff et al., 2007; Yumamoto et al., 2007); environmental reporting at the national level (Larrinaga et al., 2002; Deegan et al., 2002; O’Donovan, 2002; Burrit, 2002; Taylor \& Rafai, 2003; Șendroiu et al., 2006; Sumiani et al., 2007; Briciu \& Sas, 2008; Ivan et al., 2017). Of the methods studied and enshrined in terms of emissions in the atmosphere we can rely on Activity-Based Emissions method (ABE) (Recker et al., 2011). Another method derivative to the ABC method is the Activity-Based Budgeting method (ABB) which represents a realistic solution to the budgetary side of activities of an economic entity (Tinkler \& Dube, 2002; Essam, 2005). 
Strategic management accounting tools such as ABC/ABM can help economic entities in decision-making (Căpușneanu \& Martinescu, 2010) and in the management of environmental costs for sustainable business. The $\mathrm{ABC} / \mathrm{ABM}$ system was and is used to improve cost structure that combines their allocation mode with the process of activities management (Cokins \& Căpuşneanu, 2011), this slide allowing economic entities to allocate better resources and to improve its production processes to reduce costs.

\section{Method}

Based on the two main objectives of the scientific approach we achieved a questionnaire at the energy complex from Romania which has identified two categories of opinion of participants (managers and directors of departments) on the following questions: (1) What measurement tool of environmental performance would be indicated to use within your company? (2) The tool for measuring environmental performance can contribute to its improvement inside your company?

In this questionnaire we have been envisaged the use of information sources based on discussions and interviews, the collection and processing of data, synthesis of theoretical and practical aspects and review of the literature in the field as regards the results of research made. The sample was conducted on a number of 126 respondents, of which 42 managers and 84 directors of departments. After the analysis of the questionnaires, the analysis team presented the obtained results (table 1). In accordance with the opinion expressed by the participants in the survey, the best tool for measuring the environmental performance in the company is a mix of methods that rely on the $\mathrm{ABC}$ and $\mathrm{ABE}$ methods in the context of the run-up and planned resource management, that is to say the quadruple $A B B-A B C-A B E-A B M$. It is responsible for improving the company's performance within the energy industry, offering the possibility to measure and improve the environmental performance and ensuring a cleaner and sustainable environment.

Table 1. Categories of respondents and their answers

\begin{tabular}{|l|l|l|l|l|}
\hline \multirow{2}{*}{ Questions } & \multicolumn{3}{|l|}{ Category of respondents } \\
\cline { 2 - 5 } & \multicolumn{2}{|l|}{ Managers } & \multicolumn{2}{l|}{ Directors of departments } \\
\cline { 2 - 5 } & Yes & Not & Yes & Not \\
\hline 1. What measurement tool of environmental performance & & & & \\
would be indicated to use within your company? & & & & \\
- ABE method & 20 & 22 & 45 & 39 \\
- ABC-ABE method & 22 & 20 & 53 & 31 \\
- other methods or mix of methods & 34 & 8 & 58 & 26 \\
\hline 2. The tool for measuring environmental performance can & & & & \\
contribute to its improvement inside your company? & 32 & 10 & 67 & 17 \\
\hline
\end{tabular}

Source: Prepared by the authors. 


\section{ABB-ABC-ABE-ABM Implementation in the Economic Entities from Energy Industry}

4.1 Approaches to Environmental Components within the Mix of Methods Applied to the Level of Economic Entities

Currently, more and more economic entities integrate environmental components into own management or at the strategic level or at the operational level. Information management of these entities is geared on the collection, processing and communication of environmental information. The ownership on resources (water, air, soil etc.) cannot be of an entity that uses these resources, though its heritage is given the totality of the rights and obligations with economic value belonging to a natural person or legal and economic assets to which they relate. Therefore, an entity must take account of all aspects relating to the environment, since these contribute to cost-efficiency and profitability of the entity.

The environmental researches have established the semantic reconsiderations framework in national/international context of concepts such as: production process, cost, profit, economic growth. Therefore environmental accounting is responsible to take environmental aspects considering that they are the basis of decision-making. This reasoning also had in mind some aspects such as: (1) the limitation of financial accounting and widening its framework by including environmental aspects; (2) the performance of an economic entity includes also the environmental performance; (3) quantification of emissions is based on an appropriate model which illustrates the principle of $\mathrm{ABC}$ method adapted to the environmental component (activities consume resources, but they are not inexhaustible); (4) the provision of information related to the environment (real, accurate and on time) constitutes the guarantee of solid managerial and effective decisions.

$\mathrm{ABC}$ method consists in establishing a correlation between established activities according to the list of activities and their specific cost drivers and application of ABC-ABM for environmental costs determination involve the identification of environmental costs and environmental hidden costs in the indirect costs of an economic entity. Determination of environmental costs on costs' carriers will help identify all the activities related to the environment, but also to the total costs of the economic entity.

Environmental costs are assigned correctly as well as to the actual production and the provided production (budgeted). The non-inclusion of recycling and remediation costs of environmental aspects in the total cost of production will lead to the achievement of incorrect total costs.

Therefore, for the allocation of expenditures related to the environment will be used specific cost drivers that will take account the impact of activities on the environment. Within the analyzed entity, there have been identified three criteria or specific environmental cost drivers to which it will allocate the expenditure related to the environment: the degree of toxicity of the emissions, the volume of emissions and/or sterile dumps kept under control and emissions/the impact of emissions on the environment.

Using $\mathrm{ABC}$ method, the environmental costs are treated distinctly under the indirect costs, 
which are included in the production cost, by identifying the consumed resources, the activities and related costs (related to auxiliary sections). It is obtained a clearer record of performance in respect of each centre cost, sector of production.

From the economic point of view, taking into account by the economic entities of environmental aspects in the cost of the works, services or products to allow them a better rationalization of natural resources and energy, but also satisfying the requirements concerning respect for the environment and human health. For a better understanding of those aspects we exemplify the inclusion of environmental cost through $\mathrm{ABC}-\mathrm{ABE}$ according to the specificity of the entities from energy industry. The general framework of the initiative undertaken by the case study to the investigated entity was based on Figure 1.

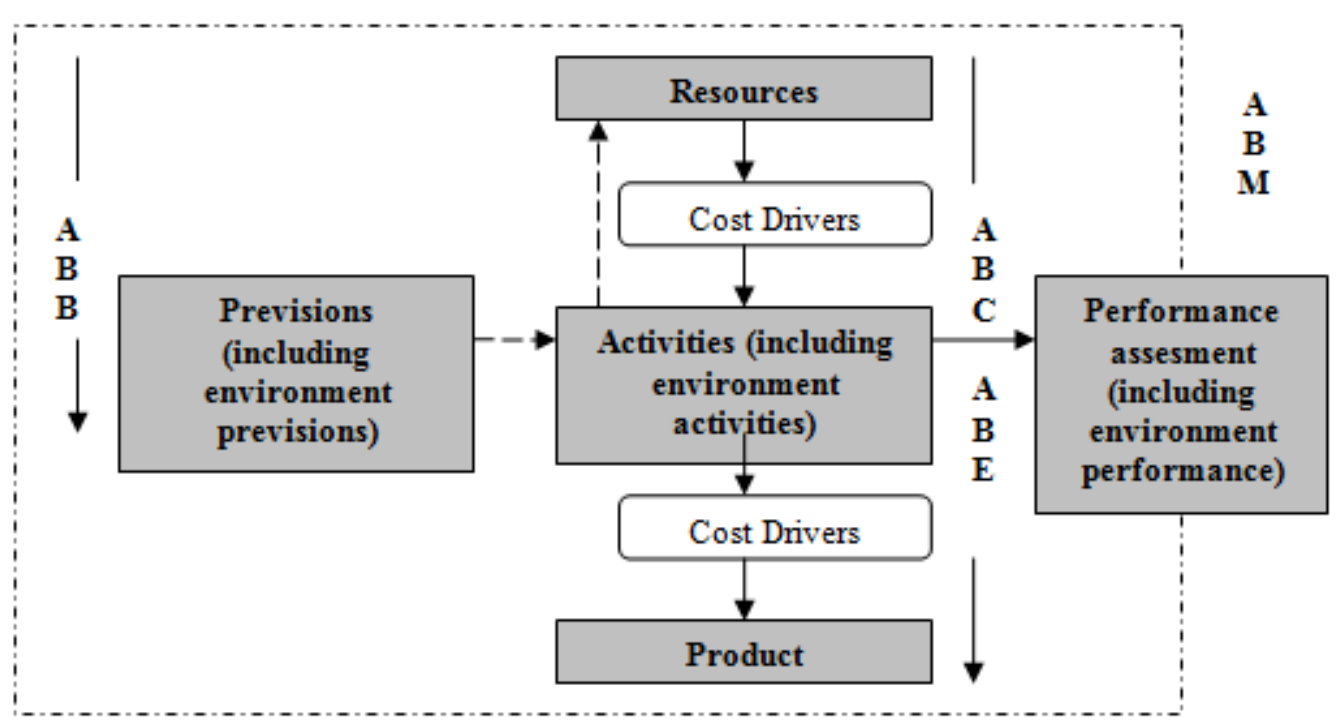

Figure 1. Using quadruple ABB-ABC-ABE-ABM within an economic entity

Source: Authors' own processing.

\subsection{Stages of $A B E$ Integration into the ABC-ABM Mix to the Level of Economic Entities}

Integrating the $\mathrm{ABE}$ analysis under the $\mathrm{ABC}-\mathrm{ABM}$ mix aims at determining and measuring emissions of $\mathrm{CO}$ into the atmosphere and the costs associated with routine cleaning emissions and other types of pollutants. Thus, the information collected may be used for the development of reporting complex situations where information relating to the environment is included in properly harnessed managers' decisions. Economic entities that already use the $\mathrm{ABC}-\mathrm{ABM}$ mix will browse through the following itinerary regarding the integration of $\mathrm{ABE}$ method:

Stage 1. Setting the products, types of emissions and their monitoring

At this stage, establishing the goal is priority to the start of the whole approach of integrating 
ABE method. Thus, the purpose of the entity subject to the analysis consists in measuring the carbon emissions in the atmosphere and related costs for the obtaining energy based on coal combustion. In order to ensure the success of the integration for the ABE method it is necessary that the whole involved staff (managers, directors of departments, direct and indirect productive personnel) to agree and to have understood the advantages offered by its implementation. On this occasion, it shall be established those responsible for monitoring and measuring the direct or indirect carbon emissions in the atmosphere based on the application of specific/local industrial standards. In determining and measuring emissions, the economic entity recorded emissions on each process/activity. The obtained data should be kept for a longer period of time to be able to perform analyses or comparisons over time.

Stage 2. Identification of processes or activities which require the determination of the $\mathrm{CO}$ and other types of pollutants

In order to establish processes or activities which consist in the determination of $\mathrm{CO}$ emissions, will be collected information on:

- Financial accounting information records regarding: wage costs, material costs, material costs, discretionary spending, vendors, customers, other expenses of the economic entity;

- Information on human resources: identification of working people (personal codes), their place of employment and their work hours;

- Information about emissions: measuring data directly or through sensors from noxious fumes or exhaust pipes;

- Information on emission factors: the quantity of emissions associated with a particular activity (e.g., $\mathrm{CO}$ expressed in $\mathrm{mg} / \mathrm{m}^{3}$ of air or the amount of waste resulting from the technological process expressed in $\mathrm{cm}$ ). Emission factors are usually supplied by a third party and will vary depending on geographical location and other variables.

- Metric information about resources and activities: the volume of the activity which creates emissions (e.g. the amount of electricity consumed by an activity).

Stage 3. Determination of cost drivers related to environmental activities or emissions drivers In order to determine $\mathrm{CO}$ emissions and other types of pollutants, these were demarcated on two areas:

- Implementation field 1 for direct $\mathrm{CO}$ emissions within the economic entity;

- Implementation field 2 for $\mathrm{CO}$ emissions arising from organizational activities, such as: waste disposal or materials purchased from third parties.

Stage 4. Calculation of $\mathrm{CO}$ emissions costs related to processes and activities based on emissions drivers and other types of pollutants

Stage 5. Determining the full cost of the product by including the costs of emissions

Determining the final cost of the product shall be carried out according to the $\mathrm{ABC}$ method, 
namely:

Total Cost $=$ Direct Costs + Indirect Costs (of activities, including the green activities)

\subsection{Case Study on Determining Depollution Costs to the Level of Economic Entities}

In the context of an economic entity in the energy industry, the following processes (activities) were identified: (1) the supply-to-sell process (activities: supply, sales); (2) the production process (activities: production, maintenance, transport, environment and depollution); (3) administrative process (activities: financial-accounting, cost-pricing, performance indicators calculation, quality assurance, organization and planning of work, personnel/salary, administrative). The situation regarding the identification of the main processes and activities of the economic entity in the energy industry is shown in Table 2 and the situation of direct and indirect expenses (by activity) in Tables 3 and 4. For example, it was chosen to determine the cost drivers for the depollution activity (Table 5) and to calculate the costs of the depollution activity (shown in Table 6).

Table 2. Identification of the main processes and activities of the economic entity in the energy industry

\begin{tabular}{|c|c|c|}
\hline Process & Main Activities & Main Activities Components \\
\hline \multirow[t]{5}{*}{ Supply-to-sell } & \multirow[t]{4}{*}{ 1. Supply } & - supplier selection \\
\hline & & - launching and reception of orders \\
\hline & & - supply plan draw up/follow \\
\hline & & - stock \\
\hline & 2.Sales & $\cdot$ coal-sell \\
\hline Production & Main Activities & Main Activities Components \\
\hline \multirow[t]{5}{*}{ Process } & \multirow[t]{2}{*}{ 1. Production } & - preparation of the works \\
\hline & & - extraction/mechanized extraction \\
\hline & 2. Maintenance & - operating machinery, repairs \\
\hline & 3. Transport & - transportation \\
\hline & $\begin{array}{l}\text { 4. Environment and } \\
\text { depollution }\end{array}$ & $\begin{array}{l}\text { - Monitoring emissions (sedimentary dusts and particulate } \\
\text { matter)/Quantity of waste resulting from the process wear } \\
\text { (cubic meter) }\end{array}$ \\
\hline \multirow[t]{11}{*}{ Managing Process } & Main Activities & Main Activities Components \\
\hline & \multirow[t]{2}{*}{ 1. Financial-accounting } & - accountability (financiary, management) \\
\hline & & -calculation, costs reckon up \\
\hline & \multirow[t]{2}{*}{ 2. Assigning costs-prices } & •costs audit \\
\hline & & •selling prices assess \\
\hline & $\begin{array}{l}\text { 3. Performance indicators } \\
\text { calculus }\end{array}$ & -performance/environment performance calculation \\
\hline & 4. Quality assurance & •quality control \\
\hline & $\begin{array}{l}\text { 5. Work organizing and } \\
\text { planning }\end{array}$ & -assess norms and regulations \\
\hline & \multirow[t]{2}{*}{ 6. Human/salary resources } & -staff manning/inventory \\
\hline & & •salarization \\
\hline & 9. Administrative & -general administration \\
\hline
\end{tabular}

Source: Prepared by the authors. 
Table 3. Situation of the direct expenses of the economic entity in the energy industry

\begin{tabular}{|l|l|l|}
\hline No. & Direct Expenses & Sum (RON) \\
\hline 01. & Consumption of raw materials & 861278.00 \\
\hline 02. & Expenditure on electricity and water & 113365.57 \\
\hline 03. & Expenditure on damping - treatment plant & 733000.00 \\
\hline 04. & Expenditure on inventory items & 4178.45 \\
\hline 05. & Expenses with GFR transport & 536200.00 \\
\hline 06. & Expenses on packaging & 253.01 \\
\hline 07. & Expenses on the materials transport & 38147.82 \\
\hline 08. & Salaries expenses & 2290308.00 \\
\hline 09. & Expenses on salaries accessories & 1124838.00 \\
\hline & Total & 5701568.85 \\
\hline
\end{tabular}

Source: Prepared by the authors.

Table 4. Situation of indirect expenses (by activity) of the economic entity in the energy industry

\begin{tabular}{|l|l|l|}
\hline No. & (Indirect) Activities Expenses & Sum (RON) \\
\hline 01. & Consumption of various materials & 3874.00 \\
\hline 02. & Fuel consumption & 3465.00 \\
\hline 03. & Spare parts & 19584.26 \\
\hline 04. & Expenses on electricity for auxiliary and main sections & 935439.85 \\
\hline 05. & Expenses related to auxiliary heating thermal energy & 29060.00 \\
\hline 06. & Expenses on amortization of auxiliary and main sections & 51633.24 \\
\hline 07. & Expenses with amortization & 405 \\
\hline 08. & Expenses on repair of auxiliary machinery equipment & 29491.76 \\
\hline 09. & Expenses on services provided by third parties for ancillary services & 551189.88 \\
\hline 10. & Expenses with antidotes for the auxiliary section & 175.38 \\
\hline 11. & Expenses on salaries related to auxiliary and principal departments & 1810500.00 \\
\hline 12. & Expenses on salary accessories related to auxiliary and principal departments & 776121.00 \\
\hline 13. & Expenses of general interest of expenditure on administrative activities & 1607351.19 \\
\hline 14. & Expenses for depollution & 67947.80 \\
\hline & Total & 5886238.36 \\
\hline
\end{tabular}

Source: Prepared by the authors.

The cost drivers identified in the environmental and depollution activities of the production process are: number of analyses resulting from emission monitoring (sedimentary powders and particulate matter); the amount of waste resulting from the wear process (cubic meter). 
Table 5. Determination of cost drivers related to depollution activities and units of measurement

\begin{tabular}{|l|l|l|l|l|l|}
\hline Process & Main Activities & Activities Components & Costs Inductors & U.M. & Quantity \\
\hline \multirow{3}{*}{ Production } & \multirow{2}{*}{$\begin{array}{l}\text { 4. Environment } \\
\text { and depollution }\end{array}$} & Emissions Monitoring & Analyses number & bulletin & 4 \\
\cline { 3 - 6 } & & Waste Monitoring & $\begin{array}{l}\text { Waste Quantity } \\
\text { resulted from the } \\
\text { wear process }\end{array}$ & $\begin{array}{l}\text { cm } \\
\text { (cubic meter) }\end{array}$ & 10050 \\
\end{tabular}

Source: Prepared by the authors.

Table 6. Calculation of depollution costs

\begin{tabular}{|l|l|l|}
\hline \multirow{2}{*}{ Expenses for depollution (RON) } & \multicolumn{2}{|l|}{ Monitoring emissions/waste } \\
\cline { 2 - 3 } & Analyses number & Waste Quantity \\
\hline $\begin{array}{l}\text { 67947.80 of which: } \\
\text { - analyses } 5208.40 \\
\text { - waste } 62739.40\end{array}$ & $1302.10 \mathrm{RON} / \mathrm{bulletin}$ & $6.2427 \mathrm{RON} / \mathrm{cm}$ \\
\hline
\end{tabular}

Source: Prepared by the authors.

Calculation of total production cost: $5701568.85+5886238.36=11587807.21 \mathrm{RON}$.

Unitary Cost on $\mathrm{kwh}$ is $=11587807.21 \mathrm{RON} / 21462876 \mathrm{kwh}=0.5399 \mathrm{RON} / \mathrm{Kwh}$

\subsection{Evaluation of Environmental Performance}

In assessing the environmental performance of an economic entity it is necessary to calculate specific environmental indices. The environmental index calculated for carbon monoxide, $\mathrm{I}_{\mathrm{CO}}$ was based on a simple mathematical formula: $\mathrm{I}_{\mathrm{CO}}=$ quantitative emission or pollutant concentration/standard emission or admissible limit value expressed in $\mathrm{mg} / \mathrm{m}^{3}$ (Rojanschi et al., 2008). According to the law no. 104/2011 on the ambient air quality with respect to the limits for the protection of human health, the permitted limit value for the CO pollutant is 10 $\mathrm{mg} / \mathrm{m}^{3}$ for 8 hours (APMH, 2017).

Based on the data from the economic entity, we calculated the carbon monoxide index $\left(\mathrm{I}_{\mathrm{CO}}\right)$ using the above formula, for the 2014-2015 time frame at the annual quantitative emission level, for the two industrial and urban areas, with the values:

- industrial base: $0.019 \mathrm{mg} / \mathrm{m}^{3}$ for 2014 and $0.016 \mathrm{mg} / \mathrm{m}^{3}$ for 2015 ;

- urban background: $0.017 \mathrm{mg} / \mathrm{m}^{3}$ for 2014 and $0.02 \mathrm{mg} / \mathrm{m}^{3}$ for 2015 .

\section{Conclusions}

The activity-based cost method provides a quantity of financial and operational information necessary to determine performance, respectively environmental performance. By taking into account the real use of equipment and resources (technological and human) within the 
activities identified through the processes at the level of the entity, the necessary information can be collected for the realization of a multi-level architecture that also highlights the information related to the environment. Based on the $\mathrm{ABC}$ analysis, the Activity-Based Emissions (ABE) analysis can be performed on each process and on each activity to determine and calculate $\mathrm{CO}$ emissions. By identifying process/activity emission drivers and determining environmental costs, the emissions-based method contributes to highlighting the impact on alternative resources that help the process. Determining the costs of emissions and adding to the other direct and indirect components of the costs can determine the costs of products, works or services. By providing an accurate view of reality, activity-based emissions analysis contributes directly to identifying the positive or negative impact of $\mathrm{CO}$ emissions on processes or activities within the entity. This information is also the basis of the process of future design of the processes and activities specific to the environment, but also the basis for decision-making by the management of the economic entity. By measuring the environmental impact of a process/activity, analysts and/or managers are determined to take into account their environmental decisions, having the ability to execute or make changes in the processes within the entity. Considering the efficiency of using the mix of methods to determine the costs or performances of economic entities, we believe that future mixes will be used between the $\mathrm{ABC}$ method and other methods used to highlight or calculate emission/immissions or other categories of pollutants at the process/activity level. Our empirical study is particularly limited, by taking into account only the narrowing of mining category - specific pollutants in determining and calculating emissions.

\section{References}

Briciu, S., \& Sas, F. (2008). Considerations regarding the pursuance and reporting of the environmental costs, 3rd International Conference Accounting and management information systems, Bucharest, 19-20 June. Accounting and Management Information Systems, Supplement.

Burritt, R. L. (2002). Environmental reporting in Australia: current practices and issues for the future. Journal of Business Strategy and the Environment, 11(6), 391-406, https://doi.org/10.1002/bse.343

Căpuşneanu, S., \& Martinescu, D. M. (2010). Convergence of ABC and ABM principles. Guarantee of a performant management. Theoretical and Applied Economics, 10, 93-102.

Chavent, M. et al. (2010). L'adoption en France des normes IFRS relatives aux incorporels: bouleversement des pratiques ou inertie?, Journée Capital immatériel: état des lieux et perspectives, Montpellier, France, 18 Juin.

Cokins, G., \& Căpuşneanu, S. (2011). Sustaining an effective ABC/ABM system, Theoretical and Applied Economics, 2, 47-58.

Deegan, C. (2002). The legitimising effect of social and environmental disclosures a theoretical foundation Accounting. Auditing \& Accountability Journal, 15(3), 282-311. https://doi.org/10.1108/09513570210435852 
Deegan, C., Rankin, M., \& Tobin, J. (2002). An examination of the corporate social and environmental disclosures of BHP from 1983-1997: a test of legitimacy theory. Accounting, Auditing and Accountability Journal, 15(3), 312-343, https://doi.org/10.1108/09513570210435861

Depoeres, F. (2004). Reporting environmental: une comparaison GRI/nre. Revue Francaise de Comptabilité nr, 364, 17-18.

Essam, M. (2005). An Application of Activity-Based-Budgeting in Shared Service Departments and Its Perceived Benefits and Barriers under Low-IT Environment Conditions. Journal of Economic \& Administrative Sciences, 21(1), 42-72, https://doi.org/10.1108/10264116200500003

Holland, L., \& Foo, Y. B. (2003). Differences in environmental reporting practices in the UK and the US: the legal and regulatory context. British Accounting Review, 35(1), 1-18, https://doi.org/10.1016/S0890-8389(02)00127-0

Hughes et al. (2001). Historical Overfishing and the Recent Collapse of Coastal Ecosystems, Science, 27(293), 5530, 629-637. https://doi.org/10.1126/science.1059199

Hunedoara Environmental Protection Agency. (APMH, 2017). [Online] available: http://apmhd.anpm.ro/web/apm-hunedoara/acasa

Ivan, O. R., Căpuşneanu, S., Topor, D. I., Oprea (Constantin), D. M. (2017). The auditing of the eco-dashboard of a company in the aluminum industry and its impact on sustainability. Journal of Environmental Protection and Ecology, 18(1), 399-409.

Jorgensen, B., \& Soderstrom, N. (2007). Environmental disclosure within legal and accounting contexts: an international perspective. Working paper, Columbia Business School.

Larrinaga, G. et al. (2002). Accountability and accounting regulation: the case of the Spanish environmental disclosure standard. Journal European Accounting Review, 723-740. http://dx.doi.org/10.1080/0963818022000001000

Larrinaga, G. et al. (2002). The role of environmental accounting in organisational change: an exploration of Spanish companies. Accounting, Auditing and Accountability Journal, 14(2), 213-239. http://dx.doi.org/10.1108/09513570110389323

Nyquist, S. (2003). The Legislation of Environmental Disclosures in Three Nordic Countries-A Comparison, 12(1), January/February, 12-25, https://doi.org/10.1002/bse.344

O'Donovan, G. (2002). Environmental disclosures in the annual report: extending the a Pageslicability and predictive power of legitimacy theory. Accounting, Auditing and Accountability Journal, 15(3), 344-371. https://doi.org/10.1108/09513570210435870

Recker, J., Rosemann, M., Gohar, E. R. (2011). Measuring the Carbon Footprint of Business Processes. In M. zur Muehlen \& J. Su (Eds.), BPM 2010 Workshops, LNBIP 66, pp. 511-520.

Rojanschi, V., Grigore, F., \& Ciomoş, V. (2008). Guide to Environmental Assessor and 
Auditor. Bucharest: Economic Publishing House.

Șendroiu et al. (2006). Environmental Managerial Accounting: Environmental Costs and Organization Decision Making. Theoretical and Applied Economics, 10.

Sumiani, Y., Haslinda, Y., \& Lehman, G. (2007). Environmental reporting in a developing country: a case study on status and implementation in Malaysia. Journal of Cleaner Production, 15(10), 895-901. https://doi.org/10.1016/j.jclepro.2006.01.012

Taylor, A., \& Rafai, S. (2003). Strategic Budgeting: A Case Study and Proposed Framework, Management Accounting Quarterly, 5(1).

Tinkler, M., \& Dube, D. (2002). Strength in Numbers, CMA Management, September, pp. 14-17. https://doi.org/10.1038/527S50a

Yamamoto, M., Distadio, L., \& Fernandes, R. (2007). Environmental disclosure in the Mining Sector in Latin America and South Africa, in 3rd International EA-SDI Conference Proceedings in Prague, pp. 209-235, Czech Republic, 2007. [Online] Available: https://ea-sdi.ujep.cz

Yusoff, H. et al. (2007). Environmental engagements through the lens of disclosure practices: a Malaysian story. Asian Review of Accounting, 14(1/2), 122-148. https://doi.org/10.1108/13217340610729509

\section{Glossary}

ABB: Activity-Based Budgeting.

ABC: Activity-Based Costing.

ABE: Activity-Based Emissions.

ABM: Activity-Based Management.

Kwh: kilowatt per hour.

\section{Copyright Disclaimer}

Copyright for this article is retained by the author(s), with first publication rights granted to the journal.

This is an open-access article distributed under the terms and conditions of the Creative Commons Attribution license (http://creativecommons.org/licenses/by/4.0/). 